\title{
Evaluation of Quality Attributes during Storage of Guava and Papaya Mixed Fruit Leather
}

\author{
Rajani Singh*, C.S. Pandey and R.K. Jhade \\ Department of Horticulture, Jawaharlal Nehru KrishiVishwaVidyalaya, Jabalpur, 482004 \\ Madhya Pradesh, India \\ *Corresponding author
}

\section{A B S T R A C T}

\section{Keywords}

Guava, Papaya, Mixed fruit leather, Pulp ratio, TSS, Acidity

\section{Article Info}

Accepted: 15 November 2018 Available Online: 10 December 2018
This study was conducted to find out the effect of blended fruit pulp and sugar treatments on quality attributes of mixed fruit leather at 0,20,40, 60, 80 and 100 days of storage. Among 18 treatment combinations, six pulp ratio of guava and papaya and three levels of sugar were used for preparation of mixed fruit leather. Mixing of guava and papaya pulp in ratio of (80:20) with $\mathrm{S} 2$ (30 gm sugar/100 gm pulp) was recorded best in sensory evaluation. In case of qualitative characters (per cent TSS and per cent acidity), a slight increase in all the treatment was recorded. Treatments with higher ratio of guava pulp in mixed fruit leather resulted into higher TSS and acidity per cent. The result also showed the product was acknowledged by evaluators as well as other consumers due to its originality, superior quality, low cost technology and wide acceptability.

\section{Introduction}

Guava is a popular tropical fruit belongs to the family myrtaceae. In India Guava is extensively produced and is fourth most grown fruit crop following Mango, Banana and Citrus (Singh et al., 2016). In year 201516 Guava cultivated area in India accounted 255 thousand $\mathrm{Ha}$, produced about 4048 thousand MT of fruits according to the Horticultural statistics at a glance 2017. Guava fruits are good source of ascorbic acid ranging from $70-350 \mathrm{mg} / 100 \mathrm{~g}$., pectin ranging from 0.52 to $2 \%$ and minerals like calcium, phosphorus, iron etc. the fruit contains substantial quantity of vitamin A, pantothenic acid, riboflavin, thiamin and niacin. Papaya belongs to the family Caricaceae, one of the most appreciated tropical fruit with great economic and nutritional importance. Papaya fruit has a sweet, exotic flavor and is rich in Vitamin $\mathrm{A}$ and $\mathrm{C}$ and antioxidants. It also contains a proteolytic enzyme, papain, which helps in digestion of protein rich foods. The vitamin A content in papaya (2020 IU/100 g) is only next to mango (Singh, 2000) and one single medium Papaya fruit provides about 224 percent of daily requirement for Vitamin C.

Guava and Papaya exhibit climacteric pattern and that is why they are highly perishable in 
nature and suffers great extent of postharvest losses. Processing can play an important role in minimizing the postharvest losses of fruits. Making of fruit leather from fresh fruits is an effective way to preserve fruits (Maskan et al., 2002). Fruit leathers are often considered as a health food and health food marketing images such as "pure," "sun-dried," or "rich in vitamins" are used to describe them (Vatthanakul et al., 2010). This study was conducted to evaluate the effect of blending of guava and papaya pulp with different ratio of sugar on quality of mixed fruit leather.

\section{Materials and Methods}

Fruits of Guava cv. Allahabad Safeda were collected from orchard of JNKVV while fruits of Papaya cv. Coorg Honey Dew were collected from fruit market, Jabalpur. Fully matured firm, ripe and healthy fruits were picked and cut into pieces. Small pieces of Guava were autoclaved at 10 psi for $5 \mathrm{~min}$. pulp is cooled to room temperature and then straining of pulp was done. Papaya fruits were peeled off and cut into pieces after removal of seeds and were autoclaved at 10 psi for 3-4 min, cooled at room temperature and then homogenization of pulp was done with mixer. Sodium benzoate (750ppm) was added to pulp after dissolving in small quantity of warm water and mixed thoroughly.For the preparation of mixed fruit leather in six different ratios (P1-80:20, P2-70:30, P3-60:40, P4-50:50, P-540:60 and P6-70:30)Guava and Papaya fruit pulp were mixed. In first six recipes 105 gm sugar (S1), in next six 210 gm (S2) and in last six recipes 315 gm sugar (S3) was added. In each pulp-sugar mixture citric acid was added. Now each recipe was homogenized in mixer for 1 minute. Then mixture of fruit pulp was poured into trays for $6 \mathrm{~mm}$ thickness, after trays were placed into sunlight, dried leathers were cut into uniform pieces and packed in polythene bags. These leathers were stored at room temperature.

\section{Flow-chart for preparation of mixed fruit leather}

Mixing of Guava and Papaya pulp

$\downarrow$

Addition and mixing of sugar and citric acid

$$
\sqrt{ }
$$

Smearing of trays with butter

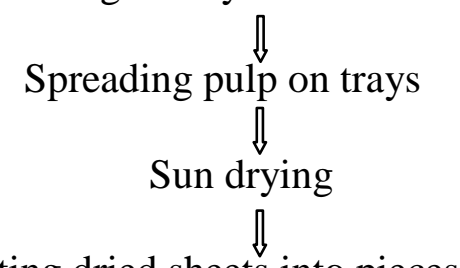

Cutting dried sheets into pieces of suitable

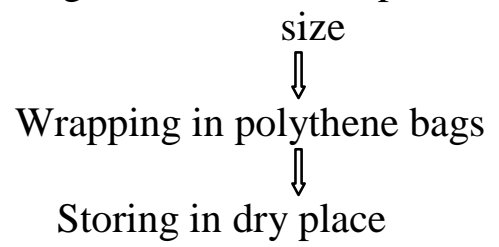

The Sensory parameters (i.e., colour, flavor, taste, texture and overall acceptability) and qualitative characters (i.e., TSS, acidity, $\mathrm{pH}$, ascorbic acid, total sugar) were recorded for freshfruit and of guava pulp and papaya pulp separately. Organoleptic quality parameters were determined by adopting anine-point hedonic scale $(1=$ Dislike extremely and $9=$ like extremely) (Amerine et al., 1965). A semi trained test penal of 10 judges did the sensory evaluation. Total soluble solids in the pulp were measured with the help of hand refractometer and $\mathrm{pH}$ of extracted pulp was measured using Elemer $\mathrm{pH}$ meter after calibration of the instrument with standard buffer solution Jain et al.,

The titerable acidity and ascorbic acid content were determined by AOAC methods (1995). The data obtained in the study were subjected to statistical analysis (Snecdecor et al., 1967).The organoleptic evaluation and testing of quality characters were carried out at 0,20 , 40, 60, 80 and 100 days of storage. 


\section{Results and Discussion}

The TSS of guava pulp was recorded 17 per cent and in case of papaya pulp it was 12 per cent. However, the values of per cent acidity for guava and papaya was $(0.45 \%)$ and $(0.38 \%)$ respectively. The Ascorbic acid was calculated $182 \mathrm{mg} / 100 \mathrm{gm}$ for guava pulp and $58 \mathrm{mg} / 100 \mathrm{gm}$ for papaya pulp. $\mathrm{pH}$ of guava and papaya pulp were found 3.97 and 6.17 respectively. Total sugar was recorded $10.50 \%$ for guava pulp and $6.5 \%$ for papaya pulp.

The overall acceptability of mixed fruit leather was computed based on the organoleptic scores of various qualities as colour, flavor, texture and taste. The results showed that maximum score (8.47) for overall acceptability found in 80\%guava + $20 \%$ papaya pulp combination (Fig. 1). It can be inferred that the blending of fruit pulp gives the better compatibility to pulp for preparation of quality leather. Combined effect of pulp ratio and different quantity of sugar was found non significant throughout the storage period of 100 days. During storage, it was observed that overall acceptability of mixed fruit leather slightly decreased as the days of storage were increased. These results are in agreements with those found by Mansy et al., (2005) in mango papaya nectar and Saravanan et al.,
(2004) in papaya jam. Baramanray et al., (2005) showed that the organoleptic rating of freshly prepared product is highly acceptable and reduced significantly with increased storage period.

Data regarding TSS of mixed fruit leather during storage have been presented in (Table 1). The highest significant value $(36.82 \%)$ of recipe $(80 \%$ guava $+20 \%$ papaya) was observed at 0 day of storage. Data revealed that higher concentration of guava pulp increased the TSS percent of mixed fruit leather and this effect was observed upto 100 days of storage. Further it was seen that per cent TSS of mixed fruit leather was increased with increased concentration of sugar also persisted for 100 days of storage. As the period of storage increased, the TSS value of mixed fruit leather increased significantly up to 100 days of storage. The increase in TSS during storage might be due to the conversion of polysaccharides like starch and pectin into simple sugar. Similar inference was drawn by findings of Sharma et al., (2008) and Jakhar $e t$ al., (2012). This might be due to conversion of some of the insoluble fraction. Similar trend was reported by Sudha et al., (2007). The increase in TSS might be due to moisture loss during storage. These findings have been well supported by Sreemathi et al., (2008).

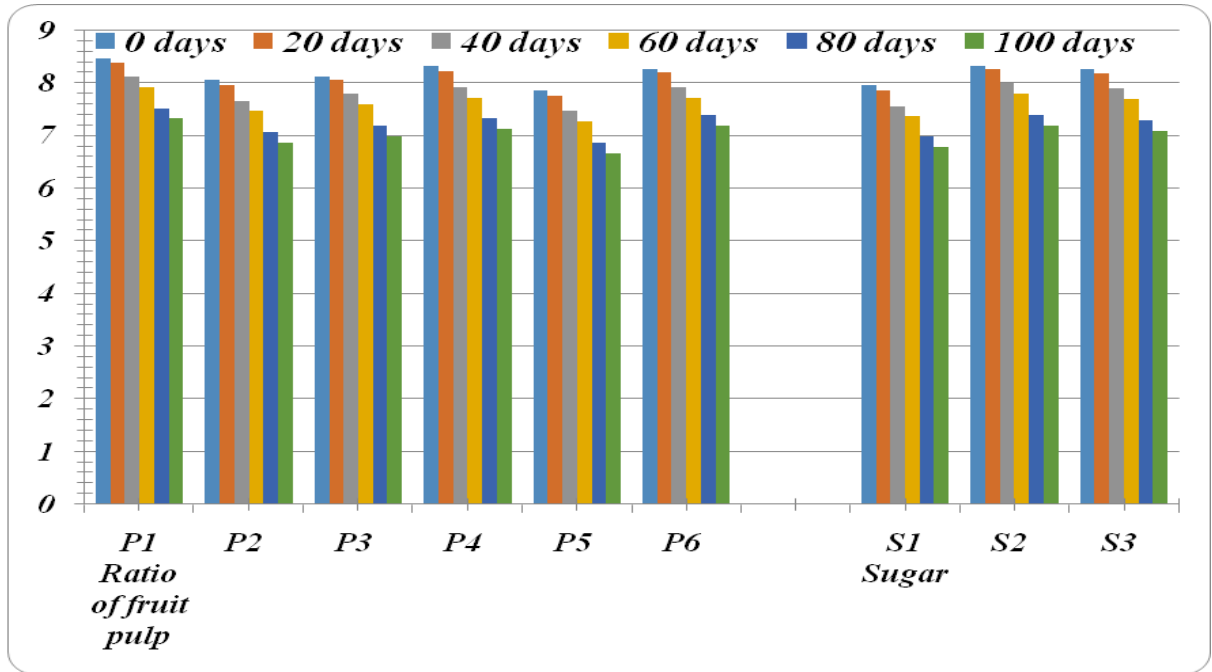


Int.J.Curr.Microbiol.App.Sci (2018) 7(12): 1888-1894

Table.1 Effect of different recipes on TSS (\%) of mixed fruit leather during storage

\begin{tabular}{|c|c|c|c|c|c|c|c|c|c|c|c|c|c|c|c|c|c|c|c|c|c|c|c|c|}
\hline \multirow{3}{*}{$\begin{array}{c}\text { Ratio of } \\
\text { fruit } \\
\text { pulp } \\
\text { FactorA }\end{array}$} & \multicolumn{4}{|c|}{0 days } & \multicolumn{4}{|c|}{20 days } & \multicolumn{4}{|c|}{40 days } & \multicolumn{4}{|c|}{60 days } & \multicolumn{4}{|c|}{80 days } & \multicolumn{4}{|c|}{100 days } \\
\hline & \multicolumn{3}{|c|}{$\begin{array}{c}\text { Sugar } \\
\text { (Factor B) }\end{array}$} & \multirow{2}{*}{$\begin{array}{c}\text { mea } \\
\mathbf{n}\end{array}$} & \multicolumn{3}{|c|}{ Sugar (Factor B) } & \multirow[t]{2}{*}{ mean } & \multicolumn{3}{|c|}{ Sugar (Factor B) } & \multirow[t]{2}{*}{ mean } & \multicolumn{3}{|c|}{ Sugar (Factor B) } & \multirow[t]{2}{*}{ mean } & \multicolumn{3}{|c|}{ Sugar (Factor B) } & \multirow[t]{2}{*}{ mean } & \multicolumn{3}{|c|}{ Sugar (Factor B) } & \multirow[t]{2}{*}{ mean } \\
\hline & S1 & S2 & S3 & & S1 & S2 & S3 & & S1 & S2 & S3 & & S1 & S2 & S3 & & S1 & S2 & S3 & & S1 & S2 & S3 & \\
\hline P1 & 30.4 & 38.03 & 42.03 & 36.82 & 30.87 & 38.63 & 43.07 & 37.52 & 31.53 & 38.87 & 43.37 & 37.92 & 32.03 & 39.63 & 43.87 & 38.51 & 32.73 & 39.87 & 44.03 & 38.88 & 33.03 & 40.07 & 44.20 & 39.10 \\
\hline $\mathbf{P 2}$ & 30 & 37.37 & 41.4 & 36.26 & 30.53 & 38.03 & 41.83 & 36.80 & 30.87 & 38.17 & 42.43 & 37.16 & 31.07 & 38.90 & 43.37 & 37.78 & 32.03 & 39.07 & 43.40 & 38.17 & 32.40 & 39.60 & 43.60 & 38.53 \\
\hline P3 & 29.03 & 36.90 & 41.07 & 35.67 & 29.67 & 37.70 & 42.70 & 36.69 & 30.60 & 38.00 & 43.07 & 37.22 & 31.20 & 38.63 & 43.07 & 37.63 & 31.37 & 39.00 & 43.23 & 37.87 & 31.63 & 39.17 & 43.40 & 38.07 \\
\hline P4 & 28.23 & 34.90 & 40.67 & 34.60 & 28.67 & 35.83 & 41.57 & 35.36 & 29.27 & 36.13 & 41.60 & 35.67 & 29.90 & 36.83 & 42.37 & 36.37 & 30.40 & 37.07 & 42.67 & 36.71 & 30.80 & 37.27 & 42.83 & 36.97 \\
\hline P5 & 27.27 & 33.13 & 39.00 & 33.13 & 28.07 & 34.17 & 40.07 & 34.10 & 28.47 & 34.83 & 40.17 & 34.49 & 29.13 & 35.80 & 41.70 & 35.54 & 29.73 & 36.17 & 42.07 & 35.99 & 30.10 & 36.40 & 42.13 & 36.21 \\
\hline P6 & 26.07 & 33.07 & 38.07 & 32.40 & 26.50 & 33.57 & 40.07 & 33.38 & 27.97 & 34.10 & 40.30 & 34.12 & 28.63 & 34.47 & 41.03 & 34.71 & 29.03 & 34.80 & 41.47 & 35.10 & 29.17 & 35.23 & 41.60 & 35.33 \\
\hline MEAN & 28.50 & 35.57 & 40.37 & & 29.05 & 36.32 & 41.55 & & 29.78 & 36.68 & 41.82 & & 30.33 & 37.38 & 42.57 & & 30.88 & 37.66 & 42.81 & & 31.19 & 37.96 & 42.96 & \\
\hline Factor & $\mathbf{A}$ & B & $\mathbf{A B}$ & & $\mathbf{A}$ & B & $\mathbf{A B}$ & & $\mathbf{A}$ & B & AB & & $\mathbf{A}$ & B & AB & & $\mathbf{A}$ & B & AB & & $\mathbf{A}$ & B & AB & \\
\hline $\mathrm{SE}_{\mathrm{m}} \pm$ & 0.10 & 0.07 & 0.18 & & 0.07 & 0.05 & 0.12 & & 0.03 & 0.02 & 0.10 & & 0.04 & 0.02 & 0.07 & & 0.04 & 0.03 & 0.07 & & 0.04 & 0.03 & 0.07 & \\
\hline $\begin{array}{c}\text { CD at } \\
5 \% \text { level }\end{array}$ & 0.31 & 0.22 & 0.54 & & 0.21 & 0.15 & 0.36 & & 0.10 & 0.06 & 0.15 & & 0.11 & 0.08 & 0.20 & & 0.12 & 0.08 & 0.07 & & 0.12 & 0.08 & 0.21 & \\
\hline
\end{tabular}


Table.2 Effect of different recipes on Acidity of mixed fruit leather during storage

\begin{tabular}{|c|c|c|c|c|c|c|c|c|c|c|c|c|c|c|c|c|c|c|c|c|c|c|c|c|}
\hline \multirow{3}{*}{$\begin{array}{c}\text { Ratio } \\
\text { of } \\
\text { fruit } \\
\text { pulp } \\
\text { Factor } \\
\text { A }\end{array}$} & \multicolumn{4}{|c|}{0 days } & \multicolumn{4}{|c|}{20 days } & \multicolumn{4}{|c|}{40 days } & \multicolumn{4}{|c|}{60 days } & \multicolumn{4}{|c|}{80 days } & \multicolumn{4}{|c|}{100 days } \\
\hline & \multicolumn{3}{|c|}{ Sugar (Factor B) } & \multirow[t]{2}{*}{ mean } & \multicolumn{3}{|c|}{ Sugar (Factor B) } & \multirow[t]{2}{*}{ mean } & \multicolumn{3}{|c|}{ Sugar (Factor B) } & \multirow[t]{2}{*}{ mean } & \multicolumn{3}{|c|}{ Sugar (Factor B) } & \multirow[t]{2}{*}{ mean } & \multicolumn{3}{|c|}{ Sugar (Factor B) } & \multirow[t]{2}{*}{ mean } & \multicolumn{3}{|c|}{$\begin{array}{c}\text { Sugar (Factor } \\
\text { B) }\end{array}$} & \multirow[t]{2}{*}{ mean } \\
\hline & S1 & $\mathbf{S 2}$ & S3 & & S1 & S2 & S3 & & S1 & S2 & S3 & & S1 & S2 & S3 & & S1 & S2 & S3 & & S1 & S2 & S3 & \\
\hline $\mathbf{P 1}$ & 0.98 & 0.95 & 0.89 & 0.94 & 0.99 & 0.97 & 0.92 & 0.96 & 1.00 & 0.98 & 0.94 & 0.97 & 1.00 & 0.98 & 0.97 & 0.98 & 1.01 & 0.98 & 0.98 & 0.99 & 1.02 & 0.99 & 0.98 & 1.00 \\
\hline $\mathbf{P 2}$ & 0.92 & 0.81 & 0.70 & 0.81 & 0.94 & 0.84 & 0.72 & 0.83 & 0.95 & 0.87 & 0.75 & 0.86 & 0.98 & 0.88 & 0.76 & 0.87 & 0.98 & 0.88 & 0.78 & 0.88 & 0.99 & 0.92 & 0.79 & 0.90 \\
\hline $\mathbf{P 3}$ & 0.84 & 0.79 & 0.66 & 0.76 & 0.87 & 0.80 & 0.68 & 0.78 & 0.89 & 0.81 & 0.70 & 0.80 & 0.90 & 0.84 & 0.71 & 0.82 & 0.91 & 0.84 & 0.72 & 0.82 & 0.92 & 0.85 & 0.74 & 0.84 \\
\hline P4 & 0.74 & 0.67 & 0.58 & 0.66 & 0.75 & 0.69 & 0.59 & 0.67 & 0.78 & 0.70 & 0.67 & 0.72 & 0.80 & 0.74 & 0.69 & 0.74 & 0.81 & 0.75 & 0.70 & 0.75 & 0.84 & 0.76 & 0.71 & 0.77 \\
\hline P5 & 0.71 & 0.65 & 0.57 & 0.64 & 0.72 & 0.66 & 0.60 & 0.66 & 0.75 & 0.67 & 0.63 & 0.69 & 0.76 & 0.69 & 0.66 & 0.70 & 0.78 & 0.71 & 0.68 & 0.72 & 0.78 & 0.71 & 0.69 & 0.73 \\
\hline P6 & 0.69 & 0.61 & 0.55 & 0.61 & 0.70 & 0.62 & 0.57 & 0.63 & 0.72 & 0.65 & 0.60 & 0.66 & 0.74 & 0.65 & 0.62 & 0.67 & 0.76 & 0.65 & 0.65 & 0.69 & 0.76 & 0.67 & 0.67 & 0.70 \\
\hline $\begin{array}{c}\text { MEA } \\
\mathbf{N}\end{array}$ & 0.81 & 0.75 & 0.66 & & 0.83 & 0.76 & 0.68 & & 0.85 & 0.78 & 0.72 & & 0.86 & 0.80 & 0.74 & & 0.87 & 0.80 & 0.75 & & 0.88 & 0.82 & 0.76 & \\
\hline Factor & A & B & $\mathbf{A B}$ & & A & B & AB & & $\mathbf{A}$ & B & $\mathbf{A B}$ & & $\mathbf{A}$ & B & $\mathbf{A B}$ & & $\mathbf{A}$ & B & $\mathbf{A B}$ & & $\mathbf{A}$ & B & $\mathbf{A B}$ & \\
\hline $\mathrm{SE}_{\mathrm{m}} \pm$ & 0.004 & 0.003 & 0.007 & & 0.004 & 0.003 & 0.007 & & 0.004 & 0.003 & 0.007 & & 0.004 & 0.003 & 0.007 & & 0.004 & 0.003 & 0.06 & & 0.004 & 0.003 & 0.007 & \\
\hline $\begin{array}{c}\text { CD at } \\
5 \% \\
\text { level }\end{array}$ & 0.012 & 0.008 & 0.02 & & 0.012 & 0.008 & 0.02 & & 0.012 & 0.009 & 0.021 & & 0.011 & 0.008 & 0.019 & & 0.011 & 0.008 & 0.019 & & 0.012 & 0.008 & 0.021 & \\
\hline
\end{tabular}


The data pertaining to the Acidity of different recipes of mixed fruit leather as affected by storage duration has been specified in (Table 2). From the study of Table 2 it can be concluded that the effect of guava pulp on acidity was prominent at every stage $(0,20$, 40, 60, 80 and 100 days) of storage. Acidity was increased as days of storage were increased up to 100 days storage period. With regard to the effect of sugar content S1 $(15 \mathrm{gm}$ sugar) had maximum acidity percent value and with increased concentration of sugar, value of per cent acidity was decreased. Further it was observed that acidity of the leather also decreased significantly with increase in sugar content. Similar result was also reported by (Jain et al., 2007)

The results inferred that formation of organic acid by degradation of ascorbic acid accounted for Increase in acidity during storage. A slight increase in acidity during storage was also reported by (Shakir et al., 2008). These findings are in conformation with the findings of (Chaudhary et al., 2006), (Manimegalai et al., 2001)and (Byanna et al., 2012).

In conclusion, on basis of Sensory scores and important quality attributes, it might be concluded that treatment where guava and papaya pulp were in ratio of (80:20) with S2 (30 gm sugar/100 gm pulp) was most efficient to retain the fruit quality attributes upto 100 days of storage under room temperature. In case of storage of mixed fruit leather at room temperature, a slight decrease in sensory attributes (colour, texture, flavor and taste) and overall acceptability in mixed fruit leather was noticed under all the treatments under study. While, in case of qualitative characters (per cent TSS and per cent acidity), a slight increase in all the treatment was recorded. The change in the quality parameters was largely dependent on different fruit pulp suagr ratio and days of storage.

\section{Acknowledgement}

Author thankful to Jawaharlal Nehru Krishi Vishwa Vidyalaya, Jabalpur, 482004 Madhya Pradesh, India

\section{Author Contributions}

Rajani Singh - Principal Author, performed analysis, interpreted data, wrote manuscript and acted as corresponding author. Dr C.S. Pandey - Research Guide, supervised development of work. R.K. Jhade Co-Author, helped to evaluate and edit of manuscript.

\section{References}

Amerine, M.A., Pangborn, R.M., and Rossler, E.B. (1965). Principles of sensory evaluation of food Academic Press, New York.

AOAC (1995). Method of Analysis of the Association of Official Agricultural Chemist, Washington, D.C., USA

Baramanray, A., Gupta, A.P., and Dhawan, S.S., (2005). Evaluation of guava (Psidium guajavaL.) hybrids for making nectar. Haryana J.Hort.Sci., 24(2): 102-109.

Byanna, C. N. and Gowda, I. N. D. (2012).Standardization of recipe for the preparation of ready-to-serve (RTS) beverage from sweet orange (Citrus sinensis Osbeck) var. sathgudi using sugar substitutes and its storage. Crop Research (Hisar); 44: 3, 356362.

Choudhary, M.L., Dikshit, S.N. and Sharma, H.G. (2006). Studies on preparation and biochemical changes in guava Ready-To-Serve beverage during storage. Indian J. of Arid Hort.1:7879.

Jain, P.K. and Nema, P.K. (2007). Processing of pulp of various cultivars of guava (Psidium guajava L.) for leather 
production. Agric. Engg. Intl. the CIGRE J., 9: 1-9.

Jakhar, M.S. and Pathak, S. (2012). Studies on the preparation and storage stability of blended ready-to-serve from ber (Zizyphus mauritiana lamk.) and jamun (Syzigium cuminiis keels.) pulp. Plant Archives 12: 533-536

Manimegalai, G., Krishnaveni, A. and Saravana Kumar, R. (2001). Processing and preservation of jack fruit (Artocarpus heterophyllus L.) bar (thandra). Fd. Sci. and Technol. Abstracts J. of Fd. Sci. and Technol. 38, 529-531.

Mansy, H.A., Sharoba, A.M., Bahlol, H.E.L.M., and Desouky, A. I. (2005). Rheological properties of mango and papaya nectar blends, Annals of Agric. Sc., Moshtohor, Vol. 43(2): 665-686

Maskan, A., Kaya, S., and Maskan, M., 2002. Hot air and sun drying of grape leather (pestil), Journal of Food Engineering, vol. 54, no. 1, pp. 81-88.

Saravanan, K., Godara, R.K. and Sharma, K.K. (2004). Studies on the storage behavior of papaya jam. Haryana $J$. Hort. Sci., 33: 218-220

Shakir, I., Durrani, Y., Hussain, I., Qazi, I. and M. Zeb, A. (2008). Physicochemical analysis of apple and pear mixed fruit jam prepared from varieties grown in Azad Jammu and Kashmir Pakistan J. of Nutrition; 7, 177-180.
Sharma, I., Kaul, R.K. and Anju, B. (2008). Effect of different treatment combinations of guava and papaya on quality and storability of ready-toserve beverages. J. Res. SKUAST J., 7: $1-8$

Singh, S.K., Sharma, M. and Singh, P.K., 2016. Combined approach of intercropping and INM to improve availability of soil and leaf nutrients in fruit trees. Journal of Chemical and Pharmaceutical Sciences 9(2), 823829.

Singh, S.P. (2000). Commercial fruits. Kalyani Publisher, Ludhiyana. Pp. 191-196.

Snecdecor, G.M., and Cochron, W.C. (1967). Statistical methods Oxford and IBH Publishing Co. Culcutta

Sreemathi, M., Sankaranarayanan, R. and Balasubramanyan, S. (2008). Sapotapapaya bar. Madras Agri. J., 95: 170173

Sudha, R., Ponnuswami, V. and Kavino, M. (2007). Value addition for long-term storage of sapota fruit products. Indian J. of Hort., 64,467-468.

Vatthanakul, S., Jangchud, A., Jangchud, K., Therdthai, N. and Wilkinson, B., 2010. Gold kiwifruit leather product development using quality function deployment approach, Food Quality and Preference, vol. 21, no. 3, pp. 339-345.

\section{How to cite this article:}

Rajani Singh, C.S. Pandey and Jhade, R.K. 2018. Evaluation of Quality Attributes during Storage of Guava and Papaya Mixed Fruit Leather. Int.J.Curr.Microbiol.App.Sci. 7(12): 18881894. doi: https://doi.org/10.20546/ijcmas.2018.712.219 